\title{
Commentary
}

\section{ICTU V. Ireland: Expanding the Scope of Self-employed Workers Entitled to Collective Bargaining Rights in Relation to Competition Law Prohibitions}

\author{
By Bas Rombouts, Associate Professor, Tilburg University, Tilburg Law \\ School, The Netherlands
}

\section{Introduction}

The decision of the European Committee of Social Rights (ECSR) in ICTU $v$. Ireland is another attempt - albeit the committee's first - at clarifying the relationship between the values of unrestricted trade and competition on the one hand and those of freedom of association and collective bargaining on the other. ${ }^{1}$ In this decision, the committee took the opportunity to analyze and explain the core purposes and principles underlying the rights to associate freely, by taking into account the international legal framework on trade union rights. By taking both a principled and pragmatic approach, the committee clarified that competition law is not meant to restrict the rights to freedom of association for those workers who may need it most and argued that Article 6(2) of the European Social Charter applies to self-employed persons such as voiceover actors, freelance journalists, and musicians. Restrictions based on commercial or competition law are not regarded as legitimate or necessary in a democratic society. After the decision, and pressure from the ICTU and

1 ECSR, Decisions on the Merits, Irish Congress of Trade Unions (ICTU) v. Ireland, Complaint no.123/2016. 
affiliated trade unions, the Committee of Ministers of the Council of Europe endorsed the decision. ${ }^{2}$

\section{Facts}

The case was brought to the ECSR in August 2016 by the Irish Congress of Trade Unions (ICTU), which argued that prior decisions by the Irish administrative authorities excluded self-employed workers from engaging in collective bargaining and that this violated Article 6 of the charter. The Irish government did not wait for a final decision from the committee but instead enacted Competition Amendment Act 2017, which included exemptions for certain categories of workers from the prohibition in Section 4 of the Competition Act 2002 in an attempt to bring the law in line with Article 6. ${ }^{3}$ Section 4 mirrors Article 101(1) of the Treaty on the Functioning of the European Union (TFEU) on the prohibition of anticompetitive agreements. ${ }^{4}$ This did not prevent the committee from undertaking a thorough review of the international and European framework on collective bargaining and freedom of association. These rights are firmly embedded in human rights law and furthermore essential tools to allow workers to participate and negotiate about their employment relationships.

\section{International and European Legal Principles}

The committee explained that the European Convention on Human Rights (ECHR) includes Article 11, by which everyone has the right to freedom of peaceful assembly and association as well as the right to form and join trade unions. ${ }^{5}$ The committee cited the case law by the European Court of Human Rights (ECtHR) in Bemir and Baykara v. Turkey ${ }^{6}$ and Hrvatski Liječnički Sindikat

2 European Trade Union Confederation, "Council of Europe recognises bargaining rights of self-employed: now EU should follow," press release, 13 December 2018, https://www.etuc. org/en/pressrelease/council-europe-recognises-bargaining-rights-self-employed-now-eushould-follow.

3 International Justice Resource Center, "European Social Rights Committee Addresses Self-Employed Workers' Collective Bargaining Rights," 8 January 2019, https://ijrcenter .org/2019/01/08/european-social-rights-committee-addresses-self-employed-workers-collective-bargaining-rights/.

4 ICTU v. Ireland, para. 17.

5 ICTU $v$. Ireland, para. 21.

6 ECtHR, Demir and Baykara v. Turkey, Application no. 34503/97, 12 November 2008. 
v. Croatia $^{7}$ to explain the essential role of collective bargaining rights. ${ }^{8}$ This is reinforced by reference to Resolution 2033 of the Parliamentary Assembly of the Council of Europe, which stresses that "the rights to bargain collectively and to strike are crucial to ensure that workers and their organisations can effectively take part in the socio-economic process to promote their interests when it comes to wages, working conditions and social rights." ${ }^{9}$

International public law also protects these rights. Article 8 of the International Covenant on Economic, Social and Cultural Rights stipulates the right to freedom of association and the right to strike; explicit guidance on collective bargaining processes is included in Convention no. 98 of the International Labour Organization (ILO) and other ILO documents. ${ }^{10}$

In the context of the European Union, Article $101 \mathrm{TFEU}$ forms the basis for the prohibition of cartel behavior and unfair competition. However, the Court of Justice of the European Union (CJEU) already held in Albany ${ }^{11}$ that collective agreements are not seen as prohibited agreements between companies because they relate to the fundamental right to bargain collectively. ${ }^{2}$ The rationale for the "Albany exception" was that the social policy objectives of this type of agreement would be substantially compromised if management and labor were subject to Article 101(1) TFEU when they collectively seek to agree on provisions that will improve work and employment conditions. ${ }^{13}$

In $F N V$ Kiem, ${ }^{14}$ the Court argued that if self-employed persons-in this case, substitute musicians - are in a situation that is comparable to employees, these "false self-employed" would fall outside the scope of Article 101 TFEU. The reasoning was that the status of self-employed persons and the status of workers are fundamentally different under EU competition law because the first category qualifies as "undertakings" and the second does not. ${ }^{15}$ However, if the situation of the substitute musicians is actually a disguised employment relationship, the "Albany exception" applies to them. ${ }^{16}$

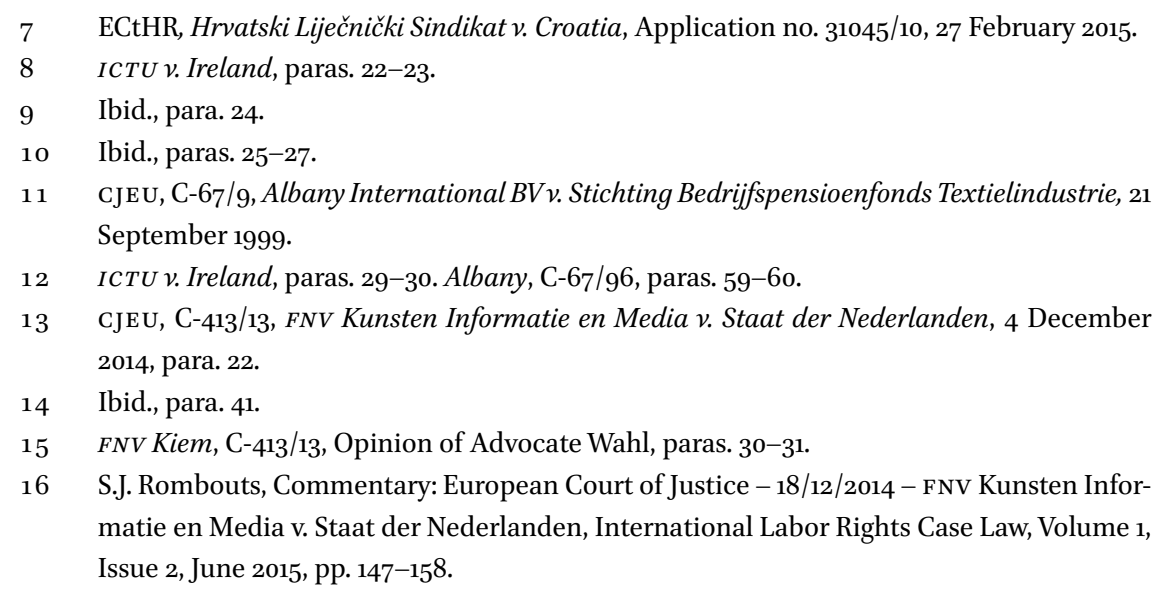




\section{Committee Assessment}

The committee decision in ICTU v. Ireland seen together with Ireland's modifications to its competition law expand the number of exceptions from competition law prohibitions by the CJEU significantly. ${ }^{17}$ Until now, the ECSR had not assessed whether self-employed workers would fall under the scope of Article 6(2) of the European Social Charter, although it had held that, in principle, the rights provided in Part II do apply to self-employed persons as well. ${ }^{18}$ The ECSR explains that nothing in the wording of Article 6 "entitles States Parties to impose restrictions on the right to bargain collectively."19 For that reason, possible restrictions are exclusively limited to those included in Article G of the charter. ${ }^{20}$

The committee reflects on current trends and argues that "the world of work is changing rapidly and fundamentally with a proliferation of contractual arrangements, often with the express aim of avoiding contracts of employment under labour law, of shifting risk from the labour engager to the labour provider." ${ }^{21}$ For those reasons, an increasing number of workers fall outside the scope of a dependent employee even though they are de facto dependent. This, the committee asserts, should be taken into account when determining the scope of Article 6(2). ${ }^{22}$

The committee also notices that the justification of collective bargaining mechanisms lies in the comparably weak position that individual suppliers of labor have when establishing the terms and conditions of their working agreements. ${ }^{23}$ This lack of bargaining power is exactly the reason that the CJEU has declared Article $101 \mathrm{TFEU}$ inapplicable to labor contracts. ${ }^{24}$ The committee emphasizes that ILO Conventions nos. 98, 151, and 154 "extend collective bargaining rights to all employers and workers and all subjects." ${ }^{25}$

Consequently, in its assessment, the ECSR considers-in relation to the previous situation before the Competition Amendment Act 2017-that the ban on collective bargaining was "excessive and therefore not necessary in a democratic society in that the categories of persons included in the notion of

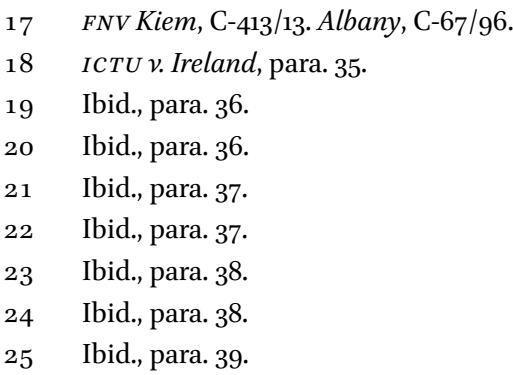


'undertaking' were over-inclusive." ${ }^{26}$ The committee did not go into the difference and scope of the categories of "false self-employed workers" and "fully dependent self-employed workers" but considered it evident that the categories under review-musicians, voiceovers, and journalists - are not in a position to influence their conditions of pay if they are denied the right to bargain collectively. ${ }^{27}$ They cannot be characterized as independent self-employed because they do not meet the criteria of having several clients, the authority to hire staff, and the authority to make strategic decisions on the business operations. ${ }^{28}$ Moreover, the committee considers it is highly unlikely that these categories of self-employed workers would significantly affect fair competition were they allowed to conclude collective agreements. ${ }^{29}$ For all those reasons, the committee concluded that the ban before the amendment to the legislation is not necessary in a democratic society and violates Article 6(2). ${ }^{30}$

The situation after the entry into force of the Competition Amendment Act 2017 however, does not amount to a breach of Article 6. The reformed legislation exempts both false self-employed workers and fully dependent self-employed workers from Section 4 of the act (the prohibition on cartel-behavior) and includes a list of self-employed workers that are automatically considered as being in those two categories (voiceover actors, session musicians, and freelance journalists). ${ }^{31}$ This list may also be expanded by a procedure that includes an application by a trade union to the minister of jobs, enterprise and innovation. ${ }^{32}$ For the majority of the ECSR this is regarded as satisfactory. However, in their dissenting opinion, Petros Stangos and Barabara Kresal disagree on the grounds that the procedure is insufficiently oriented toward results and that the minister enjoys a wide margin of discretion in the matter. ${ }^{33}$

\section{Concluding Remarks}

The decision in ICTU v. Ireland gives a clear signal that rights to organize and collective bargaining can be particularly important and even essential for

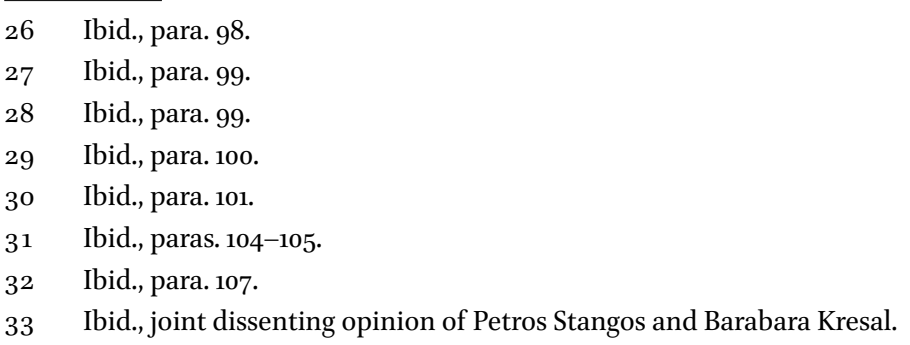


certain groups of self-employed persons. The changes made in Irish law expand the scope of categories entitled to protection in a nonexhaustive way. The Irish Competition Amendment Act 2017 creates exceptions for false self-employed persons but also for fully dependent self-employed, thereby expanding the beneficiaries of collective bargaining rights relative to earlier CJEU interpretations. ${ }^{34}$ Moreover, this act includes a process for future exemptions, which could be a way to allow for better protection of categories of self-employed people in, for instance, platform-based jobs. The ECSR emphasizes the central role of the fundamental rights to freedom of association and collective bargaining in international and European human rights law. Unrestricted trade and fair competition are highly valued principles that lead to many benefits for consumers. However, this should not impede specific groups of self-employed people in particular jobs from exercising their right to collective bargaining. This is a core democratic entitlement that is essential for groups of working people that fall outside the formal definition of dependent worker and are disadvantaged in regard to establishing the terms and conditions of their employment relation. 